\title{
Ouster Clause: Legislative Blaze and Judicial Phoenix
}

\author{
Sandhya Ram S A*
}

\section{Abstract}

If constitutionalism denotes obedience to the Constitution, the scheme for enforcement of obedience and invalidation of disobedience should be found in the Constitution itself. It is important that this scheme be clear and the task of enforcement be vested in a constitutional body. In such a situation, the question of custodianship i.e., who will ensure the rule of constitutionalism assumes prime importance, as any ambiguity regarding the same will result in conflicts uncalled for between legislature and judiciary. This conflict intensifies when judiciary determines the constitutionality of the legislations and the legislature defends by placing it in the 'ouster clauses' within the Constitution to exclude the judicial determination. Judiciary counters by nullifying the legislative attempts through innovative interpretation. An attempt is made to study Article $31 \mathrm{~B}$, the most prominent ouster clause in the Constitution of India barring judicial review of legislations and how the Indian judiciary retaliated to such legislative attempts and effectively curbed them. The study outlines the historical reasons which necessitated the insertion of Article $31 \mathrm{~B}$ in the Constitution and analyses the myriad implications of such an ouster clause within the Constitution. The constitutional basis of judicial review is studied to audit the justifiability of the open ended Ninth Schedule along with Article 31 B. A comparison between Article $31 \mathrm{~B}$ and the other ouster

* Assistant Professor, V.M.Salgaocar College of Law, Miramar, Panaji, Goa; advsandhyaram@gmail.com 
clauses namely Articles $31 \mathrm{~A}$ and $31 \mathrm{C}$ is also made, bringing out the effect and scope of Article $31 \mathrm{~B}$. The study covers a critical survey of judicial pronouncements from 1951 to 2007.

Keywords: Constitutionalism; Judiciary; Judicial Review; Ouster Clause; Ninth Schedule

\section{Introduction}

Every state has a 'Constitution' at least in the sense that it operates its important institutions according to some fundamental body of rules. ${ }^{1}$ Fundamental laws can come into existence either by express agreement among the members of a community, or at least the most powerful of them, as in the case of adoption of a written Constitution, or by gradual development of customs, as in the case of rules of succession governing traditional monarchical system. ${ }^{2}$ In both the cases, the continued existence of such laws depends on the presumption of a 'Higher $\mathrm{Law}^{3}$ mandating obedience to the fundamental laws. This is the very essence of 'Constitutionalism'4, which like Kelsen's 'grundnorm' 5 is a presumption of obedience to a Constitution, written or unwritten. The perception of such a 'Higher Law' underlying the Constitution, acts as an effective check on all institutions, be it the Parliament or the court, operating under it. It is here that the question of guardianship of the Constitution and therefore, of the higher law assumes significance. The tug of

${ }^{1}$ Encyclopaedia Britannica 84 (5th ed. 1974).

2 Jeffrey Goldsworthy, The Sovereignty of Parliament 237 (Oxford University Press 1999).

${ }^{3}$ Edward S. Corwin, The 'Higher Law' Background of American Constitutional Law, 42 HARV. L. REV. 149, 152 (1928) (Corwin considers the Higher Law as certain principles of right and justice which are eternal and immutable).

4 See 3 Carl J. Friedrich, Constitution and Constitutionalism, in Encyclopaedia of Social Sciences 318 (1968).

5 See Hans Kelsen, Pure Theory of Law, (1934) 50 L.Q.R. 485 (in every legal order, a hierarchy of 'oughts' is traceable back to some initial fundamental 'ought' on which the validity of all the others ultimately rests. This, Kelsen called the 'grundnorm' the basic or fundamental norm). 
war between the judiciary and the legislature centres on the question of 'custodianship of the Constitution'6 in countries with a written Constitution. In the absence of a written Constitution, the issue is one of sovereignty ${ }^{7}$, that is, who is the creator of all laws?

The Hobbesian theory states that at the foundation of every legal system there is a 'sovereign', who is the creator of all laws and whose power is therefore above law. ${ }^{8}$ This theory does not always fit with the facts because in many legal systems there is no sovereign in the Hobbesian sense of the term. Neither the supreme legislature is sovereign because its powers are limited by a written Constitution, nor those able to amend the Constitution are sovereign, because their authority is also conferred and controlled by its provisions. If the supreme legislature is also considered to be bound by the Constitution, then the power to check legislative aberrations invariably lies with the judiciary. Here, there is a possibility that the Parliament might evade judicial scrutiny by incorporating within the Constitution an ouster clause holding it impermissible for the court to enter certain specified areas. The device of entrenching legislations beyond the reach of the judiciary, even if they infringe the fundamental rights of the citizen, is known as the 'legislative override' and is a Canadian contribution to the

${ }^{6}$ Granville Austin, The Supreme Court and the Struggle for Custody of the Constitution, in Supreme But Not Infallible 1 (B.N. Kirpal ed., 2000) (Austin says that the issue of custody is never finally settled because the contestants for it are the most powerful institutions of Government and the balance in a system of checks and balances is never firmly horizontal).

7 See generally Goldsworthy, supra note 2 .

${ }^{8}$ See generally ThOMAS Hobbes, Leviathan (C.B. Macpherson ed., Penguin Books 1968). But see H.L.A. HART, THE CONCEPT OF LAW 50-71 (1961) (even monarchies are often governed by laws that determine who has the right to succeed to the throne, which the monarchs themselves are not able to amend. Hart argued that legal rules, rather than sovereigns, constitute the foundations of legal systems. Hart's theory of law, so effective in its criticisms of the Hobbessian theory, has itself been powerfully criticised by Ronald Dworkin, who argues that legal principles, rather than rules, constitute the foundations of legal systems). See also RONALD DWORKIN, TAKING RIGHTS SERIOUSLY 14-131 (1977). 
theory of constitutionalism ${ }^{9}$. The legitimacy of one such ouster clause within the Constitution of India is the crux of this study.

\section{The Basis of Judicial Review under the Indian Constitution}

The concept of judicial review was outlined by the Chief Justice Marshall of the United States Supreme Court in Marbury v. Madison ${ }^{10}$ wherein it was held that, "It is emphatically the province and duty of the judicial department to say what the law is...", and that

If a law be in opposition to the Constitution, if both the law and the Constitution apply to a particular case, so that the court must either decide that case conformably to the law, disregarding the Constitution, or conformably to the Constitution, disregarding the law, the court must determine which of these conflicting rules governs the case. This is the very essence of judicial duty. If then, the courts are to regard the Constitution, and the Constitution is superior to any ordinary act of the legislature, the Constitution and not such ordinary act, must govern the case to which they both apply. ${ }^{11}$

Lord Edward Coke of the Court of Common Pleas in England as early as in 1610 in Dr. Bonham's case12 had held that "When an Act of Parliament is against Common law and reason or impossible to be performed, it is void".

The Constitution of India guarantees to its citizens certain fundamental rights embodied in Part III of the Constitution. Article

9 See generally, Geoffrey Marshall, Canada's New Constitution (1982): Some Lessons in Constitutional Engineering, in CONSTITUTIONS IN DEMOCRATIC POLITICS 163 - 165 (Vernon Bogdanor ed., 1988) (similar ouster clauses were also incorporated in the Quebec Charter of Rights and Freedoms of 1975 and in the Alberta Provincial Bill of Rights of 1972).

105 U.S. 137, 178 (1803).

11 Id.

12 Thomas Bonham v. College of Physicians, 8 Co. Rep. 114. 
13, which itself is a fundamental right, embodies a general norm of Indian constitutional law that the fundamental rights of individuals should be kept inviolable from the legislative and executive encroachments. The Courts trace their power of judicial review from the reservoir of Article 13 (2), with respect to post Constitution laws. ${ }^{13}$ By virtue of this Article, the courts can strike down any law which is inconsistent with or in derogation of the fundamental rights. In other words, the Parliament of India was not meant to be a sovereign law making body. Justice Mukherjee observed in A. K. Gopalan v. State of Madras"14 "The Constitution of India is a written Constitution and though it has adopted many of the principles of the English parliamentary system, it has not accepted the English doctrine of absolute supremacy of Parliament in matters of legislation." In the words of Chief Justice Kania, "The inclusion of Article 13(1) and (2) appears to be a matter of abundant caution. Even in their absence, if any of the fundamental rights was infringed by any legislative enactment, the court has always the power to declare the enactment; to the extent it transgresses the limits invalid."15

\section{Ouster Clause in the Indian Constitution}

When the High Court's struck down various land reform legislations on the ground that it takes way the fundamental right to property of the zamindars ${ }^{16}$, the interim Parliament, by way of Constitution (First Amendment) Act, 1951, carved out an area of exception to the general rule laid down in Article 13 by adding Part

13 CONSTITUTION OF INDIA art. 13(2) (declares that "The State shall not make any law which takes away or abridges the rights conferred by this Part and any law made in contravention of this clause shall, to the extent of such contravention be void.").

14 A.I.R. 1950 S.C. 27, 91.

${ }^{15} \mathrm{Id}$. at 34 (emphasis added).

16 IX CONSTITUTIONAL ASSEMBLy DEBATES, 1195-96 (1949). 
III of the Constitution, Articles $31 \mathrm{~A}^{17}$ and $31 \mathrm{~B}$ and the ninth schedule was attached to Article 31B.

Article 31B reads thus:

Without prejudice to the generality of the provisions contained in Article 31-A, none of the Acts and Regulations specified in the ninth schedule nor any of the provisions thereof shall be deemed to be void, or ever to have become void on the ground that such Act, regulation or provision is inconsistent with, or takes away or abridges any of the rights conferred by, any provisions of this Part, and not withstanding any judgment, decree or order of any court or tribunal to the contrary, each of the said Acts and regulations shall, be subject to the power of any competent legislature to repeal or amend it, continue in force.

\section{Following are the main implications of this Article:}

a) Retrospective protection is given to the laws included in the Schedule, from the date of passing of the law and not merely from the date of entry into the Schedule.

b) The protection is against Part III challenges as a whole.

c) Thus the legislature may make any law curtailing the fundamental rights and place it in the ninth schedule by way of a constitutional amendment.

d) The Ninth Schedule shuts its door against any judicial scrutiny based on fundamental rights challenge.

e) The schedule also has the effect of nullifying judicial pronouncements both prospectively and retrospectively.

f) The overall effect is that fundamental rights are made unenforceable in law, in so far as the Ninth Schedule inclusions are concerned.

17 CONSTITUTION OF INDIA art. 31A(e) (Saving of laws providing for acquisition of estates etc. against challenges based on art. 14 and art. 19). 
g) The entries in the schedule, in spite of having been given a place within the Constitution can be repealed or amended by the competent legislature.

The Ninth Schedule unquestionably acts as a 'protective umbrella'18 which saves legislations from heavy judicial pouring. The very insertion of Ninth Schedule in the Constitution is controversial as it "creates a constitutional paradox and inner constitutional contradiction". ${ }^{19}$ On the one hand the Constitution declares that state shall not make any law which takes away or abridges any of the rights conferred by Part III, and on the other it says that the laws inconsistent with Part III cannot be challenged before a court of law if they are included in the Ninth Schedule. M.P. Jain describes Article 31B and Ninth Schedule a 'drastic' and 'an unjustifiable technique of constitutional amendment'.20 Another view is to see the mechanism as an appropriate compromise formula which sorts out the dichotomy between judicial review and legislative power. ${ }^{21}$ In matters concerning economic goals, legislature is the more competent body and in matters affecting citizens' life, liberty and equality, the judiciary should undoubtedly be the final authority.

\section{Is Article 31B Wider than the Other Ouster Clauses?}

In addition to Article 31B there are two more ouster clauses of the same genus in Part III of the Constitution namely Article $31 \mathrm{~A}^{22}$ and Article $31 \mathrm{C}^{23}$. The protective zone of Article 31B is much wider than these two ouster clauses. Even if Articles 31A and 31C also exclude

18 See generally N.K. JAYAKUMAR, JUDICIAL PROCESS IN INDIA: LIMITATIONS AND LEEWAYS (APH Publishing Corporation 1997).

19 Baldev Singh, Ninth Schedule to the Constitution of India: A Study, 37 J. INDIAN L. INST. 457, 464 (1995).

${ }^{20}$ M.P. JAIN, INDIAN CONSTITUTIONAL LAW 1408 (6th ed. 2010).

21 P. Ishwara Bhat, Limits of Ninth Schedule's Openness, 19 C.U.L.R 232, 236 (1995).

22 Inserted by the Constitution (First) Amendment Act, 1951.

${ }^{23}$ Inserted by the Constitution (Twenty Fifth) Amendment Act, 1971. 
judicial review, the exclusion is limited to challenges based on Articles 14 and 19 and that too only for laws giving effect to certain specified purposes. ${ }^{24}$ Omnipotently, Article 31B saves uncatalogued number of laws from challenge on the basis of all or any of the fundamental rights, if such laws are included in the Ninth Schedule. If not for the judicial construal, Article 31B as it reads, is capable of protecting laws which violate even right to life under Article 21, the most precious of all fundamental rights.

\section{Historical Background of Ninth Schedule}

The circumstances leading to the Constitution (First Amendment) Act, 1951, which inserted Article 31-B and the Ninth Schedule, need to be examined for a proper understanding of the purpose and scope of the Schedule. ${ }^{25}$

India had a caste based closed hierarchical system of society in which a person's status and privileges were invariably associated with the caste in which he was born. ${ }^{26}$ This in turn had a close nexus with the forms and types of land rights assigned to be enjoyed by each caste. ${ }^{27}$ The outmoded and inegalitarian structure that prevailed in pre independent India ${ }^{28}$ had resulted in unequal

24 Art. 31 A protected laws giving effect to acquisition of estates etc, while Article $31 \mathrm{C}$ immunises laws giving effect to 31(b) and (c).

${ }^{25}$ LXV LOK SABHA DEBATES, No.1. Col.116 (1977) (when the Forty Second Amendment Bill was being discussed in the Lok Sabha, Mr. Deputy Speaker was quoted "You spend too much time on background" and Shri Sezhiyan stated "Because background is the most important thing in a Constitution Amendment Bill". This is true of every constitutional amendment).

26 See B. Kuppuswamy, Social Change In India (5th ed. 1994). See also CASTE TODAY (C.J. Fuller ed., 1997); MARC GALANTER, LAW AND SOCIETY IN MODERN INDIA (1989); M.N. SREENIVAS, India: SOCIAL STRUCTURE 3-47 (1991).

27 See H.C.L. Merillat, LAND AND THE CONSTITUTION OF INDIA 110-112 (1970).

28 Id. at 113; See also Granville Austin, Working A DEMOCRATIC CONSTITUTION 73 (4th ed. 1999). 
distribution of income, wealth and disparities in the standard of living. ${ }^{29}$ So when India became independent, the nation was not as independent as the people wanted it to be. It was in the hands of the landowners, zamindars, princes, businessmen who were unwilling to contribute to the economic welfare of the nation. This was in addition to the already existing menace namely, landless labour, unemployed and under paid workers. ${ }^{30}$

\section{Congress and the Social Revolution}

The Congress, as the party of independence movement had long back been committed to the policy of 'land to the tiller', as is evident from the presidential address by Jawaharlal Nehru ${ }^{31}$ in the Lahore Session ${ }^{32}$ and also in the Karachi Resolution. ${ }^{33}$ This ardent desire of the Congress party was reflected in the Constituent Assembly deliberations. The social revolution was put at the top of the agenda by the Constituent Assembly when it adopted the objectives resolution ${ }^{34}$ which called for social, economic, and political justice and equality of status and of opportunity for all. Thus what they aimed at was to create a document, "The Constitution of India' which would pave the way for an egalitarian society. In this pursuit, there was the case of defining and prioritising social, economic and political justice. There was also the problem of liberty versus justice.

29 DAda Bhai NaOroji, POVERTy AND UN- BRITISH RUle IN INDIA 34 (1962); See also, RUDDAR DATT \& K.P.M.SUNDARAM, INDIAN ECONOMY 121-122 (1990).

30 RAJEeV DHAVAN, THE AMENDMENT: CONSPIRACY OR REVOLUTION 17-18 (1st ed. 1978).

31 See, 1 DOROthy NORMAN, NeHRU ThE FIRST SiXTY YeARS 204-205, 249 (1965).

32 LAHORE SESSION (Dec. 29, 1929).

33 KARACHI SESSION, Resolution on Fundamental Rights and Economic Policy (Aug 6-8, 1931).

34 See 1 Constitutional Assembly Debates (Dec. 13, 1946) (Jawaharlal Nehru prepared and moved the resolution). 
The Indian Constitution sought a balance between the principles of liberty and justice by containing within Part III, two articles viz., Articles 19(1)(f) and 31.35 The former provided for the individual freedom to acquire, hold and dispose of property and the latter gave power to the state to acquire property for public purpose after paying compensation. The paradox is that the proposed balance created all the more imbalances as the issue involved the delicate nexus between the individual's right to property and the public interest. These two often overlap and generate conflicts. According to Jawaharlal Nehru, these two conflicting interests can be balanced "to some extent by legal means, but ultimately the balancing authority can only be the sovereign legislature of the country which can keep before it all the various factors - all the public, political and other factors..." 36 Regarding the compensation to be paid to the property owners, he observed:

Parliament fixes ... the compensation ... and they should not be challenged except ... where... there has been a fraud on the Constitution ... . But normally speaking, one presumes that any Parliament representing the entire community of the nation will not commit a fraud on its own Constitution and will be very much concerned with doing justice to the individual as well as to the community. ${ }^{37}$

It was further observed:

No Supreme Court and no judiciary can stand in judgment over the sovereign will of the Parliament representing the will of the entire community.... sometimes even the legislature may go wrong, but ultimately the fact remains that the Legislature must be supreme and must not be interfered with by the Courts of law in such measures of social reform. ${ }^{38}$

${ }^{35}$ Deleted by the Constitution (Forty-fourth Amendment) Act, 1978.

36 IX CONSTitutional Assembly DebAtes, 1193 (1949) (Jawaharlal Nehru was speaking on the draft Article 24, which corresponds to Article 31).

${ }^{37} \mathrm{Id}$.

${ }^{38} \mathrm{Id}$. at $1195-1196$. 
The work to be done by the courts and their prohibitions ${ }^{39}$ were thus clearly spelt out in the Constituent Assembly, as far as the individual right to property was concerned. With the Constitution coming into force, the courts lost no time in safeguarding individual freedoms guaranteed by the Constitution, totally disregarding the spirit of the framers of the Constitution in bringing about the social revolution. Three cases ${ }^{40}$ which were filed by the zamindars and other intermediaries challenging the zamindari abolition laws, reached the High Courts wherein the impugned statutes were held violative of one or the other of the fundamental rights of the petitioners. The makers of the Constitution wanted the court to defend the liberties of the citizen, at the same time render support to governmental social welfare programs. But the courts also had to ensure that these schemes were not inconsistent with the basic principles of libertarian socialism enshrined in the Constitution. All these made the position of the judges of the infant nation very difficult. Moreover, as rightly pointed out by a writer, "To think that a small group of judges trained in the methods of English law, could be transformed into social revolutionaries overnight, was also too much to expect." 41

39 The prohibition being that the courts are not to transform itself into a third chamber.

${ }^{40}$ Kameshwar Singh v. State of Bihar, A.I.R. 1951 Pat. 91; West Bengal Settlement Kanungoe Cooperative Society v. Mrs. Bela Banerjee, A.I.R. 1951 Cal. 111; Subodh Gopal Bose v. Bihari Lal Dolui, A.I.R. 1951 Cal. 85.

${ }^{41}$ Rajeev Dhavan, Justice on Trial: The Supreme Court Today 25 (1980). See also James S. Read, The New Common Law of the Commonwealth: The Judicial Response to Bill of Rights, 25 COMMONWEALTH L. Bull. 31, 34 (1999) (the writer notes that in 1950s in India (where courts performed remarkably better) the application of fundamental rights got off to an economically inactive start as lawyers and judges confronted the novelty of such provisions in a common law context). 


\section{The First Amendment to the Constitution: A Remedial Measure}

The constituent assembly itself became the Interim Parliament of the country in 1950 - '51. It made the Constitution First Amendment Act, 1951 which inter alia inserted Articles 31A and 31B in Part III of the Constitution and the Ninth Schedule was appended to Article 31B. These provisions were inserted for fully securing the constitutional validity of zamindari abolition laws in general and certain specified state acts in particular. ${ }^{42}$

\section{Was Ninth Schedule of the Constitution meant to be Open Ended?}

There are two views regarding the 'openness' of the Ninth Schedule of the Constitution. ${ }^{43}$ The narrow view is that Article 31B imposed a definite and determinate restriction on the fundamental rights by carving out of their sphere of operation thirteen specified statutes. These Acts could have been placed under Article 31B itself, the schedule was merely for convenience. Therefore what the later amendments had done was that the Article was implicitly reenacted in its entirety, in respect of a fresh set of laws. According to the broad view, Article $31 \mathrm{~B}$ imposed an indefinite and indeterminate restriction on the fundamental rights through a schedule mechanism, indicating that its contents could fluctuate from time to time. As Blackshield observed, "It inserts into Part III itself a proviso which might be paraphrased: provided that these guarantees shall not apply to such statutes as the Parliament may schedule from time to time" ${ }^{44}$

The words 'no law providing for' in Article 31A and 'no law giving effect to' in Article 31C indicate that, whenever laws are made for a particular purpose, they are protected against certain fundamental rights. This is in contrast to the words 'none of the Acts... specified

42 See The Constitution (First Amendment) Act, 1951.

43 See A.R. Blackshield, Fundamental Rights and the Economic Viability of the Indian Nation, 10 J. INDIAN L. INST. 57, 101-102 (1968).

${ }^{44} \mathrm{Id}$. at 102 (emphasis added). 
in the Ninth Schedule' which projects a different connotation, that is, the protection from any of the fundamental rights is afforded only to the Acts and regulations which are already specified in the Ninth Schedule. To substantiate this interpretation it is submitted that while Articles 31A and 31C mandate presidential assent to the state laws as a condition precedent to avail protection. Nothing in Article 31B suggests about future inclusions into the schedule.

When the schedule was first added to the Constitution, it had thirteen Acts, all dealing with land reforms. When some members of the Select Committee ${ }^{45}$ had wanted certain more statutes to be included in the schedule, Jawaharlal Nehru requested them not to press the matter and observed thus:

It is not with any great satisfaction or pleasure that we have produced this long schedule. We do not wish to add to it for two reasons. One is that the schedule consists of a particular type of legislation ... and another type should not come in. Secondly, every single measure included in this schedule... has gone through a process of examination, analysis and scrutiny and we can take a certain responsibility about it. If you go on adding . . . it is not fair . . . or just to this Parliament or to this country. ${ }^{46}$

These words indicate that the schedule was not designed to be a permanent mechanism to escape from unfavorable decisions. Article $31 \mathrm{~B}$ and its appended Ninth Schedule was simply a convenient legislative device for asserting that those thirteen Acts were valid. Thereafter, the idea was conceived that other Acts could be brought within the protective umbrella of Article 31B by adding their titles to the Ninth Schedule.

The true purpose of the schedule was to save the land reform legislations from being challenged in courts of law. The deviation from this purpose occurred right from Jawaharlal Nehru's time,

45 The First Amendment Bill was referred to a Select Committee of 21 members including Jawaharlal Nehru, Ambedkar and Rajagopalachari.

${ }^{46}$ XII Parliamentary Debates, Part II, Col. 9632 (May 16, 1951) (emphasis added). 
when his government placed laws other than land reform laws in the schedule. ${ }^{47}$ Since then started the marathon legislative effort of filling the schedule. Presently, the schedule contains 284 entries of which 137 are original Acts and 147 are amending Acts to those already included in the schedule.

The most serious aberration occurred during the period of national emergency on the ground of internal disturbance, when The Representation of the People Act, 1951, Maintenance of Internal Security Act, 1971 and the Prevention of Publication of Objectionable Matters Act, 1976 found its way into the immunity zone. ${ }^{48}$ However these three statutes were later deleted by the Constitution (Forty Fourth Amendment) Act, 1978. It is to be remembered that the judiciary could have done nothing about this deviation even if the Parliament had not decided to delete these detestable entries. Even now, there remains in the schedule an odd set of statutes like some sections of the Motor Vehicles Act, 1939 and the Essential Commodities Act, 1955.

The more recent abuse of the schedule can be seen in the Constitution (Seventy Sixth Amendment) Act, 1994 which added a reservation law $^{49}$, which provides for $69 \%$ reservation, in the schedule. This was made deliberately to override the judicial pronouncements 50 that fixed the $50 \%$ rule as the permissible

47 Constitution (Fourth Amendment) Act, 1955 (inserted seven Acts, of which only four were land reform laws, the other three being on insurance, railways and industries).

48 The first two statutes were inserted by the Constitution (Thirty-ninth Amendment) Act, 1975 as entries 87 and 92 and the third statute was inserted by the Constitution (Fortieth Amendment) Act, 1976 as entry 130.

49 The Tamil Nadu Backward Classes, Scheduled Castes and Scheduled Tribes (Reservation of Seats in Educational Institutions and of Appointments or Posts in the Services under the State) Act, No. 44 of 1994 (1993).

50 M.R. Balaji v. State of Mysore, A.I.R. 1963 S.C. 649 (the 50\% rule laid down was conditionally confirmed in Indra Sawhney v. Union of India, A.I.R. 1993 S.C. 447). See also Devadasan v. Union of India, A.I.R. 1964 S.C. 179; State of Kerala v. N.M. Thomas, A.I.R. 1976 S.C. 490; A.B.S.K. Sangh v. Union of India, A.I.R. 1981 S.C. 298; K.C. Vasanth Kumar v. State of 34 
quantum of reservation. The court in Indra Sawhney $v$. Union of India ${ }^{51}$ had allowed relaxation from the 50 per cent rule and explained that any relaxation has to be exercised with extreme caution and with special care ${ }^{52}$ and should be determined on the basis of facts and circumstances of each case. 53 Hence, it is submitted that any fifty plus rule should inevitably be subjected to judicial review, lest the existence of special circumstances would be left to be decided by the unstructured discretion of the authority concerned. Therefore, shutting the doors of judicial scrutiny in such areas would prove to be a death knell of principle of equality and rule of law.

\section{Judicial Review of the Ninth Schedule}

Judiciary can respond to the ouster clause like the Ninth Schedule in one of the two ways. It can either abide by the legislative instruction or refuse to enter the forbidden areas or it can evolve its own judicial device to break through the legislative scheme. To analyse the mindset of the judiciary in this area, it becomes necessary to rove through the court's field of activity.

It was to overcome the difficulties created by judicial pronouncements in State of Bihar v. Kameshwar Singh ${ }^{54}$ and similar other cases $^{55}$ that the Ninth Schedule was inserted into the Constitution. The court in turn, lost no time in jumping over the

Karnataka, A.I.R. 1985 S.C. 1498; Chakradhar v. State of Bihar, A.I.R. 1988 S.C. 959.

51 A.I.R. 1993 S.C. 477.

52 See id. at 566 (as per Jeevan Reddy,J., who delivered the majority judgment).

53 See id. at 666 (as per Sawant,J., in his concurrent judgment).

54 A.I.R. 1952 S.C. 252, 261 (In this case, three judges of a five judge bench upheld the Patna High Court's verdict and ruled the impugned provisions invalid, even though the First Amendment Had placed it in the Ninth Schedule, supposedly beyond judicial scrutiny). See also Krishnan Thangal v. State, A.I.R. 1971 Ker. 65.

55 CONSTitutionAl Assembly DEBATES, supra note 36. 
legislative hurdle by striking down legislations in the schedule on the ground of legislative incompetence. In Kameshwar Singh, Patanjali Sasthri, J., found that the placing of statutes in the Ninth Schedule provides no immunity from attacks based on lack of legislative competence. Rather, Articles 31A and 31B afford only limited protection against only one ground of challenge, namely violation of fundamental rights. However in Dhirubha Devisingh Gohil v. State of Bombay56, the court extended the protection of the schedule to laws made under the Government of India Act, 1935 which violated Section 299 of the Act ${ }^{57}$. In a host of cases, ${ }^{58}$ the courts endured to carry out the legislative intention by immunising the Ninth Schedule entries from Part III challenges. The most recent challenge of the protected Acts arose in I.R. Coelho v. State of Tamil $N a d u^{59}$ where the court held that to invalidate a Ninth Schedule entry, mere incompatibility with fundamental rights are insufficient, rather it should violate the basic structure of the Constitution.

56 A.I.R. 1955 S.C. 457.

57 Government of India Act, 26 GEO. V \& 1 EDW. VIII CH. 2 (1935), §299 (dealt with the right to compensation in cases of land acquisition).

58 State of West Bengal v. Naba Kumar, A.I.R. 1961 S.C. 16; State of U.P. v. Brijendra Singh, A.I.R. 1961 S.C. 14; Gopalakrishna Yachendra v. Krishna Yachendra, A.I.R. 1963 S.C. 842; Ram Kissen v. Divisional Forest Officer, A.I.R. 1965 S.C. 625; Latafat Alikhan v. State of U.P., A.I.R. 1973 S.C. 2070; Hasmukhalal v. State of Gujarat, A.I.R. 1976 S.C. 2316; Dattatrey Govind Mahajan v. State of Maharashtra, A.I.R. 1977 S.C. 915; State of Maharashtra v. Mansingh Padvi, A.I.R. 1978 S.C. 916; Ambalal Golakbhai v. State of Gujarat, A.I.R. 1982 S.C. 1090; Sanwal Ram v. Addl. District Magistrate, A.I.R. 1982 Raj. 139; Nityanand Guru v. State, A.I.R. 1983 Ori. 54; Bapi Raju v. State of A.P., A.I.R. 1983 S.C. 1073; Lingappa Appelwar v. State of Maharashtra, A.I.R. 1985 S.C. 389; Dattatrya Shankarbhat Ambalgi v. State of Maharashtra, A.I.R. 1989 S.C. 1796; A.G. for India v. Amratlal Prajivandas, A.I.R. 1994 S.C. 2179.

${ }^{59}$ A.I.R. 2007 S.C. 861. 


\section{Retrospective Validity of Legislations}

In spite of the express words "... none of the Acts... shall be deemed to be void or ever to have become void ..." in Article 31B, doubts have been raised regarding the retrospective effect of the Acts etc. included in the schedule. The Supreme Court in $L$. Jagannath $v$. Authorised Officer ${ }^{60}$ held that ". . . such curing of the defect $^{61}$ took place with retrospective operation from the dates on which the Acts were put on the statute book." 62 However, this retrospective operation of legislations sometimes causes hardship, as it may affect bonafide transactions. The evil is greater when the provisions are related to levy of penalty and forfeiture. The result would be that citizens could even be prosecuted for offences supposed to have been committed, even before the enabling Act was validated by insertion into the Ninth Schedule.

\section{The Scope of Amending Acts}

The scope of the amendments included in the schedule was often under the shadow of doubt. The courts took the same view in all such cases ${ }^{63}$ viz., that the protection can only apply to the Acts in the schedule and not to the subsequent amending Acts unless they

60 A.I.R. 1972 S.C. 425.

61 Article 31B has cured the defect of unconstitutionality in the Acts etc. by placing them in Schedule IX.

62 L. Jagannath v. Authorised Officer, A.I.R. 1972 S.C. 425, 435. See also Subrahmanyam Chetty v. The AO, Land Ceilings, A.I.R. 1967 Mad. 422, 424 (the Court remarked that such retrospective law should not be enforced strictly).

63 See Abdul Rahiman v. Vithal Arjun, A.I.R. 1958 Bom. 94, 97-98; Ramanlal Gulabchand Shah v. State of Gujarat, A.I.R. 1969 S.C. 168, 174; Sant Singh v. State of J\&K, A.I.R. 1959 J\&K 35, 38-39; Sajjan Singh v. State of Rajasthan, A.I.R. 1965 S.C. 845, 855; State of Maharashtra v. Madhav Rao Patil, A.I.R. 1968 S.C. 1395, 1400; State of Orissa v. Chandrasekhar Singh Bhoi, A.I.R. 1971 S.C. 398, 400; Ramendra Nath v. State of W.B., A.I.R. 1975 Cal. 325, 329; Sri Kalimata Thakurani v. Union of India, A.I.R. 1981 S.C. 1030. 
are also included in the schedule by means of amendment to the Constitution. Any other interpretation would in effect confer upon a subordinate legislature the power of amending the Constitution.

\section{The Validity of Notifications Made Under the Provisions of the Entries of the Ninth Schedule}

It would be pertinent to enquire into the availability of the protective zone, in relation to the notifications etc. made by the governmental authorities under the enabling provisions of the statutes which find a favourable place within the Ninth Schedule. This query assumes even more relevance taking into consideration the enormity of the discretionary powers which might be granted to the administrative functionaries in making rules.

In Vasanlal Maganbhai v. State of Bombay64, a notification issued under an enabling provision of a protected Act was under challenge. The petitioner argued that though the enabling Act was saved under Article 31B, the notification had in substance amended that provision and thus it amounted to a fresh legislation to which Article 31B cannot apply. Gajendragadkar, J., speaking for the majority held that if the Act is saved, then the enabling provision in the Act and therefore the notification made under that provision are also automatically saved.65 Conversely, Subbarao, J., who delivered a dissenting judgment observed that "It is the duty of this court to strike down . . . any blanket power conferred on the executive by the legislature" 66 and cautioned that "If a legislature can legally be permitted to lay down a broad policy in general terms and confer arbitrary powers on the executive for carrying it out, there will be an end of the doctrine of the rule of law." 67 It is submitted that one cannot but agree with Subbarao, J. on this point. In a country governed by the Constitution and rule of law, it would

64 A.I.R. 1961 S.C. 4 (the impugned notification was challenged on the ground of excessive delegation).

65 Vasanlal Maganbhai v. State of Bombay, A.I.R. 1961 S.C. 9.

${ }^{66} \mathrm{Id}$. at $11-12$.

${ }^{67} \mathrm{Id}$. at 13 . 
only be improper to give unbridled power to the administration and the Ninth Schedule to the Constitution can be no exception to this rule. Judiciary began to take a different view in the matter in the next decade. A seven judge bench of the Supreme Court in $\mathrm{M} / \mathrm{s}$ Prag Ice $\mathcal{E}$ Oil Mills $v$. Union of India ${ }^{68}$ gave a strict construction to Article $31 \mathrm{~B}$ and held that the protection does not extend to orders and notifications issued under the protected enactments. Considering the wide ambit of Article 31B, it is submitted that if protection is given to administrative orders and notifications, it would enable the administrators not only to make arbitrary rules but also to enforce them with retrospective effect. ${ }^{69}$ Therefore, rule of law demands that courts are not to be ousted of their power of review in this area.

\section{Constitutionality of the Ouster Clause: The Judicial Voyage}

The amending power of the Parliament has been a bone of contention right from the beginning. ${ }^{70}$ "The Indian Supreme Court", as Professor Upendra Baxi remarked, "is probably the only court in the history of humankind to have asserted the power of judicial review of amendments made to the Constitution."71 The

68 A.I.R. 1978 S.C. 1296, 1309 (the Mustard Oil (Price Control Order 1977 issued under section 3 of Essential Commodities Act, 1955, which is a Ninth Schedule entry, was challenged as violative of arts.14, 19(1)(f) and $19(1)(\mathrm{g})$. Chandrachud C.J., speaking for the majority observed that fundamental rights cannot be permitted to be diluted by implications and inferences). See also Ajay Kumar Banerjee v. Union of India, A.I.R. 1984 S.C. 1130, 1145; S.S.M.T Co-operative Society v. State of M.P., A.I.R. 1977 S.C. 441,442. But see Thampan Thomas v. State, A.I.R. 1976 Ker. 94.

${ }^{69}$ N. Krishna Raju Reddiar v. A.O., Land Reforms, A.I.R. 1967 Mad. 352, 356 (the Madras High Court warned against such a possibility).

70 See 3 H.M. SEERVAI, CONSTITUTIONAL LAW OF INDIA (4th ed.1993) (for a detailed history of the conflict between the legislature and the judiciary in the context of amendment of the Constitution).

71 Upendra BAXI, COURAge, CRAFT ANd Contention 64 (1985) (Prof. Baxi describes the judicial journey through the Constitution Amendments as a Pilgrim's Progress which finally ended at the shrine of Basic Structure). 
earliest manifestation of the fight over 'custody of the Constitution' was the Constitution (First Amendment) Act, 1951 which inserted inter alia Articles 31A and 31B in Part III of the Constitution.

The prime issue in Sankari Prasad v. Union of India ${ }^{72}$ was whether the Constitution (First Amendment) Act, 1951, which inserted Articles $31 \mathrm{~A}$ and $31 \mathrm{~B}$ was ultra vires and unconstitutional. It was argued that Articles $31 \mathrm{~A}$ and $31 \mathrm{~B}$ in fact makes changes in the constitutional power of the Supreme Court under Article $132^{73}$ and Article $136^{74}$ and that of the High Court under Article $226^{75}$ of the Constitution. The Constitution provides that such amendments need to be ratified by not less than one half of the state legislatures. ${ }^{76}$ The petitioner contented that since the requirement of ratification was not fulfilled in the case of the First Amendment, it was void and unconstitutional. Rejecting this argument Patanjali Sasthri, J., speaking for the five judge bench held:

These articles do not either in terms or in effect make any change in Art.226 or in Arts. 132 and 136 .... Only a certain class of cases has been excluded from the purview of Part III and the courts could no longer interfere, not because their powers were curtailed in any manner or to any extent, but because there would be no occasion hereafter for the exercise of their powers in such cases. ${ }^{7}$

It is submitted that it is very difficult to accept this interpretation made out by Sasthri, J., as far as Article 31B is concerned. Though no express change is made in the provisions dealing with the

\footnotetext{
72 A.I.R. 1951 S.C. 458.

73 CONSTITUTION OF INDIA art. 132 (Appellate Jurisdiction of Supreme Court in appeals from High Courts in certain cases).

74 CONSTITUTION OF INDIA art. 136 (Special leave to appeal by the Supreme Court).

75 CONSTITUTION OF INDIA art. 226 (Power of High Court to issue certain writs).

76 See CONSTITUTION OF INDIA art. 368(2)(e).

77 Sankari Prasad v. Union of India, A.I.R. 1951 S.C. 458, 464 (emphasis added).
} 
jurisdiction of the courts, the effect of Article 31B is to curtail the power of the courts to some extent by foreclosing the possibility of judicial review in respect of ninth schedule entries. When an amendment of such high amplitude was made, the appropriate procedure would have been to get it ratified by the state legislatures. Hence the amendment ought to have been declared void for want of legislative procedure.

The Supreme Court in Sajjan Singh v. State of Rajasthan ${ }^{78}$ confirmed the decision in Sankari Prasad and once again upheld the constitutional validity of Article 31B. The constitutional bench found that the genesis of Articles 31A and 31B was to assist the state legislatures "to give effect to the economic policy in which the party in power passionately believes to bring about much needed agrarian reform." 79 In this way, the pith and substance of the provision was found relating to agrarian reforms and not affecting the power of courts.

The Court in I.C. Golaknath v. State of Punjab ${ }^{80}$ enunciated the new doctrine of prospective overruling and therefore, the constitutionality of the schedule was upheld in respect of all previous amendments. The future additions to the schedule by way of constitutional amendments were restricted from taking away or abridging the fundamental rights. Subbarao C.J., declared that "Parliament will have no power from the date of this decision to amend any of the provisions of Part III of the Constitution so as to take away or abridge the fundamental rights..." 81 The Ninth Schedule, though expressly do not form part of Part III, the

\section{A.I.R. 1965 S.C. 845.}

${ }^{79} \mathrm{Id}$. at 853 (though a plea to reconsider Shankari Prasad was raised, the Court rejected it on the ground that it would lead to the inevitable consequence of rendering invalid the First and Fourth Amendments and that a large number of judicial decisions regarding the validity of the Acts included in the Ninth Schedule would also be exposed to serious jeopardy) See also id. at 855.

80 A.I.R. 1967 S.C. 1643.

81 I.C. Golaknath v. State of Punjab, A.I.R. 1967 S.C. 1643, 1669 (emphasis added). 
amendments which the learned judge warned against is in effect part and parcel of the very same Part III. This is evident from the observation of Wanchoo, J. in the same case that, ". . Article 31B . . . is a legislative drafting device which compendiously puts in one place amendments which would otherwise have been added to the Constitution under various Articles in Part III . . . . What the Parliament in fact did ... was to amend various provisions in Part III." 82

Enunciating the true nature and object of Article 31B, Hidayatullah, J. lamented thus, "Ours is the only Constitution in the world which carries a long list of ordinary laws which it protects against itself.... The true intent is to silence the courts and not to amend the Constitution." 83

\section{The Basic Structure Doctrine and its Impact on Ninth Schedule}

Overruling Golaknath the Supreme Court in Kesavananda Bharativ. State of Kerala ${ }^{84}$ by a 7:6 majority held that Parliament can amend fundamental rights, but subject to the retention of the basic structure of the Constitution. A reading of the basic structure doctrine together with the holding that the Ninth Schedule insertions by way of Twenty Ninth Amendment was valid leads to either of the following implications.

i. Ninth Schedule does not offend the basic structure, or

ii. The two state Acts which were then inserted in the schedule do not offend the basic structure.

82 Id. at 1687.

${ }^{83} \mathrm{Id}$. at 1716 (according to the learned Judge, giving protection to such legislations can "hardly merit the description amendment of the Constitution").

84 A.I.R. 1973 S.C. 1469 (the Court felt it too late to question the validity of the Schedule, as it had been valid since it was enacted. In this case, the Constitution (Twenty - ninth Amendment) Act, 1972 which inserted two Kerala Acts in Schedule IX was upheld). 
If the second overtone is accepted, it would make the picture even foggier because of the vague connection between ordinary laws and basic structure of the Constitution. Masodkar, J. in Vithal Rao Udhrao Uttarwar $v$. State of Maharashtra ${ }^{85}$ asserted that an ordinary law cannot be subjected to challenge on the ground of basic structure and that for the purpose of the law it retained the character of a law made by the legislature. It is submitted that, it is nothing but a crude tactic to speak of the same letters as 'amendment' for one purpose and as 'law' for another purpose, both the interpretations being directed towards the same goal namely, saving of the legislation. If it was 'law' as Masodkar, J., said, then would it not constitute 'law' for the purpose of Article 13(2)? When such a question is posed, the term 'law' suddenly takes the colour of an 'amendment' and shields itself from Article 13(2). So the resultant effect is that, the legislation at the same time not only gets immunity offered by Article $31 \mathrm{~B}$ but also evades from basic structure challenge on the plea of being an ordinary law.

The gravest blow against the applicability of basic structure test manifested in Indira Nehru Gandhi v. Raj Narain86, where the constitutionality of an election law ${ }^{87}$ inserted in Ninth Schedule was in issue. The Constitution Bench abstained from reviewing the impugned legislation on the ground that Article 31B barred judicial review and that basic structure was applicable only to constitutional amendments and not to ordinary legislations. ${ }^{88}$ The

85 A.I.R. 1977 Bom. 99, 122 (appeals from this decision were dismissed by the Supreme Court in Dattatreya Govind Mahajan v. State of Maharashtra, A.I.R. 1977 S.C. 915).

86 A.I.R. 1975 S.C. 2299. See Prashant BHUShan, The CASE THAT SHOOK INDIA (1978) (for a detailed narration of the case from the filing of the petition to the final judgment of the Supreme Court).

87 Representation of People (Amendment) Act, 1974 (which changed the election law relating to corrupt practices and expenses with retrospective effect).

88 See Indira Gandhi v. Raj Narain, A.I.R. 1975 S.C. 2299, 2332, 2388 (Ray, C.J., opined that application of basic structure theory to ordinary legislation would denude the legislative power and encroach on the separation of powers. Mathew, J., considered the basic structure doctrine 
ordinary laws, therefore, are to be tested on the touchstone, namely the Constitution.

It is submitted that the outcome of such an interpretation is that the Ninth Schedule is deemed as a law above the 'Higher Law' namely the Constitution. One can by no stretch of imagination accept an argument which allows the basic features of the basic law to be denuded by an ordinary law. As Professor Baxi opined, "It is certainly difficult to understand at a common sense level, why the basic structure limitation on higher (constituent) power may not operate upon lesser (legislative) power." 89 Ninth Schedule laws, though ordinary laws, when viewed as the creation of a simple majority of a state legislature, by way of their being injected into Ninth Schedule of the Constitution through a constitutional amendment, and should be seen as part of the basic law. So they should be amenable to the basic structure test. Accepting the dictum in the Election Case $e^{90}$ as far as the Ninth Schedule is concerned it would mean that the ordinary laws in the schedule are allowed to pass through the key hole of the iron gate of basic structure.

The remarkable feat in this cloudy area can be found in the unanimous decision of a five judge bench in Waman Rao v. Union of India ${ }^{91}$. In this case, the court fully realised that the schedule was becoming dense and that some planning had become imperative, when it made the following pronouncement-

All Acts ... included in the Ninth Schedule prior to April 24, 1973 will receive the full protection of Article 31 B . . Acts and Regulations which are or will be included ... on or after April 24, 1973 will not receive the protection ... for the plain reason that in the face of the judgment in Kesavananda Bharati, there was no justification for making

as a vague and indefinite yardstick to determine the validity of an ordinary law).

89 UPENDRA BAXI, SUPREME COURT AND POLITICS 62 (1980).

90 Indira Gandhi v. Raj Narain, A.I.R. 1975 S.C. 2299.

91 A.I.R. 1981 S.C. 271. 
additions to the Ninth Schedule with a view to conferring a blanket protection on the laws included therein. ${ }^{92}$

Thus in Waman Rao, though constitutionality of the schedule was upheld it was specifically made subject to the doctrine of basic structure, laid down in Kesavanda Bharati. ${ }^{93}$ Interestingly, the same test of basic structure, which shall not possibly be used to check the validity of legislation, as per Indira Gandhi was applied to executive acts in S.R. Bommai 94 .

\section{Judicial Soliloquy}

Even while going by the legislative intention, the courts in certain cases thought about the injustice arising out of the impugned legislations covered by the cloak of Article 31B and Ninth Schedule. In Srikalimata Thakurani v. Union of India ${ }^{95}$, Fazal Ali, J., remarked, “Unfortunately ... though the provisions ... perilously border on arbitrariness ... we cannot however strike down these provisions because they ... fall within the protective umbrella and are immune from challenge." 96 Similarly in another case, the court had pointed out the glaring anomalies and inconsistencies in the impugned provisions and exclaimed that, "Even if the constitutionality of the measure be not open to attack, its

92 Waman Rao v. Union of India, A.I.R. 1981 S.C. 271, 291.

93 See also Minerva Mills v. Union of India, A.I.R. 1980 S.C. 1789; Bhimsinghji v. Union of India, A.I.R. 1981 S.C. 234; Sri Kalimata Thakurani v. Union of India, A.I.R. 1981 S.C. 1030; Sri Durundeswar Math v. State of Karnataka, A.I.R. 1983 N.O.C. 169; Panipat Woolen and General Mills Co. Ltd v. Union of India, A.I.R. 1986 S.C. 2082.

94 S.R. Bommai v. Union of India, (1994) 3 S.C.C. 1. See V.N. SHUKLA, CONSTITUTION OF INDIA 1012 (M.P. Singh ed., 11th ed. 2008) (for a discussion on applicability of basic structure test on legislations).

95 A.I.R. 1981 S.C. 1030 (West Bengal Land Reforms Act, 1955 gave unconfined discretionary power to the authority to disallow the tenant to resume cultivation of land left uncultivated by the bargadar).

${ }^{96}$ Id. at 1033. 
reasonableness is certainly open to challenge at the governmental level." 97

The final declaration on the nature and character of protection provided by Article 31B to the laws added to the Ninth Schedule by amendments made after Kesavananda was made by a nine judge bench of the Supreme Court in I.R. Coelho v. State of Tamil Nadus8, wherein the court was also called upon to reconsider Waman Rao. The fundamental question in this case was whether after basic structure doctrine was propounded, it was permissible for the Parliament under Article $31 \mathrm{~B}$ to immunise legislations from fundamental rights by inserting them into the Ninth Schedule and, if so, what was its effect on the power of judicial review of the Court.

\section{Constitutional Validity of Article 31B: A Gliding Hypothesis}

Y.K. Sabharwal, C.J., speaking for the unanimous bench observed that the constitutional amendments under challenge in Kesavananda Bharati were examined assuming the constitutional validity of Article $31 \mathrm{~B}$, as its validity was not in issue in that case. ${ }^{99}$ In this case also the court proceeded on the same assumption while deciding on the extent and nature of immunity that Article 31B can validly provide. The court justified its assumption by holding that "mere possibility of abuse is not a relevant test to determine the validity of a provision" 100 and so refused to make any assumption about the alleged abuse of power.

It appears that constitutional validity of Article 31B has not been challenged since Sankari Prasad wherein the First Amendment Act,

97 Krishnan Thangal v. State of Kerala, A.I.R. 1971 Ker. 65, 73 (as per Gopalan Nambiar, J.).

98 A.I.R. 2007 S.C. 861 (the order of reference made by a Constitution Bench of Five Judges in I.R. Coelho (Dead) by LRs. v. State of Tamil Nadu, (1999) 7 S.C.C. 580).

${ }^{99}$ I.R. Coelho v. State of Tamil Nadu, A.I.R. 2007 S.C. 861, 879.

$100 \mathrm{Id}$. 
1951 was challenged on procedural impropriety as also on the constitutionality of amending fundamental rights, both claims stood refuted. In Sajjan Singh, the court refused to reconsider the decision in Sankari Prasad as to the amendability of fundamental rights, with the result that the validity of the First Amendment remained unshaken. In Golak Nath, even though the amendability of fundamental rights was disallowed, the doctrine of prospective overruling allowed the First Amendment and therefore the constitutional validity of Article $31 \mathrm{~B}$ was retained. Since then, the constitutional validity of Article $31 \mathrm{~B}$ was assumed by the court as it was not directly challenged in any of the later cases. It is interesting to note that the challenges since Kesavananda Bharati always rested on the constitutional validity of particular entries to the schedule and not on the scheme allowing such a compromise on fundamental rights. The hesitation of the court to alter long standing and finalised transactions account for the continued validity of an ouster clause like Article $31 \mathrm{~B}$ despite the fact that judicial review constitutes an avowed basic structure of the Constitution. 101

\section{Scope of Judicial Review after Kesavananda: Ousting Fictional Immunity}

The Supreme Court allowed the legitimacy of the amendments to insert laws incompatible with fundamental rights in the Ninth Schedule and thereby attempt to immunise them. Nevertheless, the laws so added to the schedule shall be subject to the right of the citizens to challenge them on the enlarged judicial review concept. The authority which enacts the law cannot oust judicial review and grant deemed validity to the laws. The validity of the laws can be ascertained only by an independent organ, which is none other than the judiciary. ${ }^{102}$ The court emphasised on the 'impact test' and held that "the power to grant immunity at will on fictional basis without full judicial review, will nullify the basic structure

${ }^{101}$ See L. Chandrakumar v. Union of India, A.I.R. 1997 S.C. 1125.

102 I.R. Coelho v. State of Tamil Nadu, A.I.R. 2007 S.C. 861, 891. 
doctrine."103 Thereby, the delicate and difficult task of ascertaining the degree and necessity of legislative invasion on fundamental rights was assumed by the judiciary. It is submitted that with such a pronouncement the nine judge bench has endeavored to banish the capacity of the legislative wing to oust the review power of the courts. 'Full judicial review' and not just limited judicial review, therefore forms the core of basic structure. If limiting judicial review by granting deemed validity to the laws nullifies the basic structure doctrine, as held in this case, it is a matter of imprudence to retain any ouster clause, especially Article $31 \mathrm{~B}$ in the Constitution. The utility of Article 31B, hereafter poses a serious dilemma because the citizen can challenge a Ninth Schedule law, notwithstanding Article 31B.

\section{The Ground of Challenge: Connecting Basic Structure and Core Fundamental Rights}

The court having resumed to itself the power to examine the entries to the Ninth Schedule for determining whether the constitutional amendments by which they are put in the Ninth Schedule damage or destroy the basic structure of the Constitution, carved out the two level technique of such a full judicial review. At the first level, the violation of rights of Part III is required to be determined. Only if it is found to be violative, the second level review would apply, where the impact of violation is to be examined to ascertain whether in effect and in substance, it destroys the basic structure of the Constitution as reflected in Article 21 read with Article 14 and 19 and the principles underlying them. If the finding is in the affirmative, the law would suffer from invalidation. However, if the validity of any Ninth Schedule law has already been upheld, it would not be open to challenge such law again on the ground that it violates the basic structure of the Constitution. When a law which was held to be violative of any rights in Part III is subsequently incorporated in the Ninth Schedule after 24th April, 1973, such a

${ }^{103}$ Id. at 892 (emphasis added). 
violation shall be open to challenge on the ground that it destroys or damages the basic structure. 104

It is submitted that the 'essence of the rights test' as laid down in Coelho adds a fundamental rights flavour to the basic structure doctrine in the sense of drawing a conclusive presumption that any violation of basic structure invariably violates the golden triangle of Articles 14, 19 and 21. To put it in other words, the court presumes that only that which contravenes the legal principles underlying the golden triangle of rights is capable of violating the basic structure of the Constitution. This leads to a deduction that any amendment which is destructive of basic structure of the Constitution will also be violative of the core of Part III. This in turn secures to the citizen the unabridged right to use his fundamental right under Article 32 to challenge any such amendment to the Constitution, leave alone Article 31B. It is to be remembered that amendments to the Constitution can be challenged only on the ground of breach of basic structure, and the petitioner hereafter is allowed to deem that basic structure and the underlying principles behind the golden triangle are so intricately fastened together that no breach of one is possible without the breach of the other. Accordingly, automatic maintainability is allowed to a petition contending violation of basic structure of the constitution, subject to locus standi having been established. The ultimate gain, arising out of such a construction, is of the judiciary, because the source of judicial review of an amendment will be impliedly traced to Article 13 (2). An enlarged judicial review concept can thus be read into Article 13(2), which could be paraphrased as follows, "The Parliament shall not make any amendment to the Constitution which takes away or abridges the principles underlying the fundamental rights under Article 14, 19 and 21 and any amendment made in contravention of this rule, shall to the extent of such contravention, be void".

${ }^{104}$ I.R. Coelho v. State of Tamil Nadu, A.I.R. 2007 S.C. 892. 


\section{Conclusion and Suggestions}

The Ninth Schedule was an outcome of the conflicts between legislature and judiciary arising out of challenges to socio economic legislations. Property being no longer a fundamental right, challenges based on it would no more invoke the courts' review power under Article 13. Hence there is no pressing need to retain the Ninth Schedule in the Constitution.

Ninth Schedule was intended to safeguard the policies of the government of the time. This is a wrong trend, because with the change of governments their policies also change. If social justice via land reform legislations was the policy of the government immediately after independence, disinvestment, denationalisation or compulsory licensing of life saving drugs may be the policy of the government at different points of time. A part of the Constitution should not be reserved to serve as an immunity zone to the policies of the government, constitutional or otherwise, of the time. If at all the schedule is to be retained in the Constitution, it should be thoroughly circumscribed by means of a specified constitutional purpose. That is, the schedule should contain legislations of a specified subject or purpose only.

The legal relationship between the state and the individual has evolved over the years from subject hood requiring blind obedience and presumption of perfection of law to 'citizenship of entitlement' demanding governmental accountability. ${ }^{105}$ This relationship has further evolved into 'global citizenship' asserting the existence of basic human rights of individuals independent of any constitution, which is the theme of 'world constitutionalism'106. Therefore, constitutionalism is no more about mere obedience to any obscure

105 See Dawn Oliver, "What is happening to Relationships between the Individual and the State? ", in THE CHANGING CONSTITUTION 441 (Jeffrey Jowell \& Dawn Oliver eds., 2nd ed. 1989).

106 See generally World CONSTITUTIONALISM (Dr. Anthony D'Souza \& Dr. Carmo D'Souza eds., Cambridge Scholars Publishing 2007). 
constitution rather it is regarding limitations on governmental powers. A democratic constitution with entrenched fundamental rights confirms the existence of basic human rights and ensures their protection. Constitutionalism denotes adherence to the fundamental values underlying such a Constitution; safeguarding the identity of the Constitution and promoting 'constitutional sovereignty'. Constitutionalism, for its viability, requires as its guardian a wise and independent judiciary, with good sense of justice exercising well defined power of judicial review. Any legislative attempt to exclude such a power, by means of an ouster clause, that too within the constitution is antithesis to constitutionalism. 